\title{
Sustainable Fisheries Principles in Fisheries Management Regulation in Indonesia
}

\author{
Sapriani $^{1}$, Jamal Wiwoho ${ }^{2}$, I Gusti Ayu Ketut Rachmi Handayani ${ }^{3}$ \\ ${ }^{1.2 .3}$ Faculty of Law, Universitas Sebelas Maret \\ Surakarta, Indonesia \\ sapriani@student.uns.ac.id
}

\begin{abstract}
The purpose of this study is to determine the principles of sustainable fisheries in fisheries management regulations in Indonesia. This research is a doctrinal analysis that uses the method of literature study, with a statutory and conceptual approach. The results showed that the sustainable fisheries management regulation was implemented in the form of laws, government regulations, ministerial regulations, director general regulations, including the RPJMN 20202024. The substance of the regulation is the prohibition of fishing using certain fishing gear and the estimated number of allowed catches, which in this case was developed by the National Commission of Fishery Assessment (Komnas Kajiskan). Fishery Assessment was tasked with providing recommendations to the minister in setting the estimate. In addition, the Republic of Indonesia's fisheries management area map was also set, which became a guideline for granting fishing licenses, supervision, and law enforcement.
\end{abstract}

Keywords-Fisheries Management, Regulation, Sustainable.

\section{INTRODUCTION}

Indonesia is the largest archipelagic nation[1], which has 17,504 islands spread from Sabang to Merauke, with a coastline length of $108,000 \mathrm{~km}$ and ranks $4^{\text {th }}$ in the world [2]. Therefore, it is very natural that the Indonesian constitution states that Indonesia is an achipelagic nation. This is as outlined in Article 25 of the 1945 which has been amended state "... Indonesia is an archipelagic country characterized by the archipelago ...".

The wide and rich waters and their fishing potential make the fisheries sector have a very big role in the development of the national economy. Data from the Ministry of Maritime Affairs and Fisheries noted that the marine economic potential reached Rp. 3000 trillion and only Rp. 291.8 trillion. Besides that the Indonesian sea also has a wealth of biodiversity (biota), both marine flora and fauna so that the archipelago sea is known worldwide as "mega-biodiversity". The wealth of marine flora in the archipelago includes mangroves, seagrass beds, and coral reefs. In addition, the waters of the archipelago also provide other potential such as seaweed, sponges, pearls, and shellfish [3].

Despite having enormous economic and social potential value, fisheries are badly affected by overfishing and environmental damage [4]. Overfishing occurs because fishes are caught at a faster rate than the speed at which they reproduce. Increasingly sophisticated fishing technology and the demand for fish which have led to overfishing and ultimately led to certain species of fish becoming extinct or endangered. In the long run, if this overfishing practice is not prevented it could have a bad impact on the marine environment because the disruption of the food chain and fish's natural habitat will be destroyed [5].

In line with the aforementioned, WWF in its 2015 report entitled "Reviving the Ocean Economy: The case for Action" said that more than two-thirds of the annual economic value of the oceans depends on the condition of marine health to maintain the value of economic income per year that can be generated. Weakening of the fisheries sector, mangrove deforestation, as well as the loss of coral reefs and seagrass beds constitute a threat to the driving wheel of the marine economy which underpins life and a source of world life. In addition, climate change is also a major cause of declining sea health conditions. With the current rate of increase in temperature, estimated in 2050, coral reefs that provide food, work and protect hundreds of millions of people from storms will become extinct. Another thing that also causes a decline in marine health is overfishing. It is estimated that around 90 percent of the available world fisheries has been overexploited or fully exploited, such as Pacific Bluefin Tuna has fallen by 96 percent [6]. 
A global agreement on sustainable development was reached at the $70^{\text {th }}$ General Assembly of the United Nations (UN), which discussed the new universal development agenda as set out in the "Transforming Our World: The 2030 Agenda for Sustainable Development (SDG's)," and was attended by 193 heads of states and governments. The results of the agreement in the SDG's brought five fundamental principles that balance the economic, social, and environmental dimensions, specifically: 1) People (human), 2) Planet (earth), 3) Prosperity, 4) Peace, and 5) Partnership (cooperation). These five basic principles are known by the term $5 \mathrm{P}$ and shelter 17 Objectives and 169 Objectives that cannot be separated, connected, and integrated with each other in order to achieve a better human life [7].

Besides that, the development strategy that has been set out in the Sustainable Development Goals (SDG) is very dependent on four development strategy paths. The four development strategies consist of: (a) increasing the average quality of economic development (pro-growth); (b) creating and expanding employment (pro-job); (c) increasing community welfare through pro-poor social safety net programs; and (d) improve the quality of environmental management (pro-environmental). These four strategies must be implemented by the states in relation to the possibility of full participation from the community [8].

The success of the SDGs' agenda is highly dependent on the active role of participating countries to protect their natural resources, including in the field of fisheries. However, in its implementation there are many challenges faced by the State of Indonesia such as the lack of protection of marine and coastal ecosystems in some areas, the high level of illegal fishing, and the imbalance of marine infrastructure that triggers inequality in many ways. All of this requires good, transparent and accountable arrangements, so that the hope of sustainable fisheries as one of the world's food sources can be achieved.

\section{RESEARCH METHOD}

This research is a doctrinal law that uses library study. The legal material used is primary legal material that include legislation starting from the 1945 Constitution, laws, and other regulation related to research problems. Legal information sources include secondary legal materials such as reference books, legal journals, and scientific works that is relevant to the research topic [9].

\section{FINDINGS AND DISCUSSION}

\section{Natural Resource Management Theory}

The depletion of fish resources in the world is believed to be caused by an open access regime that considers fish supply as unlimited and can recover by itself [10]. The open access regime moves to forms of management that restrict access to fish resources, among others by using a rights-based approach that creates a property rights regime for natural resources. One form of ownership rights regime is common ownership (common/collective property), where local communities hold exclusive rights to fish in a certain area [11].

The form of common ownership in fisheries is likened to the open access situation written by Hardin in his article entitled tragedy of commons. Capistrano citing Lynch's opinion clarifies that Hardin does not refer to the tragedy of commons but rather the tragedy of open access, which is contradictory to the management and ownership of resources by a particular group. This form of management of natural resources with open access does not restrict anyone from accessing and exploiting a resource. Ostrom quoted Ciriacy-Wantrup and Bishop clearly giving a different regime of open access ownership where no one has the legal right to exclude everyone by utilizing a resource. While in common property, group members have some clarity. The group has the legal right to exclude members outside the group from utilizing the resource [12]. In the joint ownership regime, fisheries management is carried out by community-based fisheries management as a source owner (co-management) [13].

In Indonesia, the regulation on the use of natural resources, including fisheries, is the authority of the state. This authority received its legitimacy through Article 33 paragraph (3) of the 1945 Constitution as a result of the Fourth Amendment which states " The earth and water and natural resources contained therein are controlled by the state and used for the greatest prosperity of the people", in which the subsequent regulations are governed by law.

The word controlled by the state must be interpreted to include the meaning of control by the state in a broad sense, which originated and derived from the conception of the sovereignty of the Indonesian people over all sources of wealth "earth, water, and natural resources contained therein", including also in the sense of common ownership by the people's collectivity of the intended sources of wealth. The people collectively constructed by the 1945 Constitution gave a mandate to the state to hold five things: policy (beleid), administration (bestuursdaad), regulation (regelendaad), 
management (beheersdaad), and supervision (toezichthoudensdaad) [14].

In relation to fisheries management, the state is given the authority to determine the arrangement and implementation of its designation, use, supply and preservation. The aquatic environment; which is a factor of fisheries production consisting of sea water, fresh water and brackish water as the main production factors; is also under state authority. This gives very minimal involvement in fisheries management to the community.

Broadly speaking, environmentally sustainable development is development that does not neglect environmental sustainability, maintains environmental harmony and resources so that sustainable development for the present generation and future can be sustained by the existence of a sustainable environment and resources. In this case, environmentally sustainable development means the management of resources to improve the welfare of the current generation without reducing the ability of future generations to manage resources to improve their welfare. In accordance with this, Brundtland Report in WCED said the principle of sustainable development is the development that is able to meet the needs of the current generation without compromising the fulfillment of the needs of next generations.

The concept of development includes three aspects: economic, social, and environmental. These three aspects are interrelated with one another. Thus, it can be said that sustainable development does not only involve aspects of economic and social development but must also be based on environmental protection [15]. Furthermore, fisheries development goals can be grouped into various categories of objectives; namely economic, social and environmental categories. Each of these objectives when viewed from three dominant aspects of management; namely the aspects of sustainability, efficiency, and equity (equality); according to IGAK Rachmi Handayani it is difficult to fulfill all of these aspects in an integrated manner.

For example, the dimensions of fisheries management based on the conservation of fish resources strongly supports the aspect of sustainability, but does not support economic efficiency that is based on the balance between supply and demand. On the other hand, it will also reduce the catchment area and income of fisheries businesses (entrepreneurs, fishermen) and/or the availability of jobs. Or on the dimensions of increasing fishermen's income by applying open access fisheries policy, it will strongly support the economic aspects and equality (welfare) of fishermen, but is proven dangerous to the ecology, and even lead to overfishing.

Related to this in order to fulfill the country's commitment in the development of sustainable fisheries management, Law No. 31 of 2004 on Fisheries amended by Law No. 45 of 2009. In the amendment, the principles of fisheries management are not only paying attention to aspects of the preservation of fish resources as regulated in the previous Act, but also adheres to the principle of sustainable development. Therefore, the principle of fisheries management that will be built is the principle of sustainable development.

\section{Sustainable Fisheries Principles}

There are three sustainable development strategic objectives mentioned in Article 2 paragraph (2) of the Presidential Regulation No. 59 of 2017 on the Implementation of the Achievement of Sustainable Development Goals, namely: (1) maintaining sustainable improvement of the community's economic welfare; (2) community social life sustainability; and (3) maintaining the quality of the environment and inclusive development and the implementation of governance that is able to maintain the improvement of the quality of life from one generation to the next.

Sustainable fisheries management targets the availability of policies, legal frameworks, and instruments on national sea spatial planning, including the management of 11 Fisheries Management Areas (Wilayah Pengelolaan Perikanan/WPP) as stipulated in Ministerial Regulation of the Ministry of Marine and Fisheries No. 18 of 2014. Several policies and regulations issued by the government in 2015-2019 include updating fish stock data, fishing vessel monitoring systems, fishing port master plans (including location permits and management permits in WP3K). However, neither the law, the government regulations, the ministerial regulations specifically regulates the indicators of sustainable fisheries management achievements.

The principle of sustainability is one of the pillars of marine and fisheries development determined by the KKP, besides sovereignty and prosperity. The principle of sustainability in question refers to the management and protection of marine and fishery resources based on environmentally friendly principles so that it can continue to preserve resources. The forms of sustainability, namely (a) optimizing marine space, conservation, and marine biodiversity management; (b) increasing the sustainability of capture fisheries and aquaculture 
businesses; and (c) improving the competitiveness and logistics systems of marine and fisheries products. These principles are the achievements of the KKP's performance as outlined in the 2015-2019 KKP Strategic Plan but are not specifically outlined in the form of its achievements.

\section{Arrangement for Sustainable Fishery Management}

Legal politics of fisheries management in Indonesia adheres to the principle of sovereignty and jurisdiction over Indonesia's territorial waters. Therefore, marine policy at the beginning of independence was more focused on claims and strengthening of sovereignty over the Territorial Sea and Exclusive Economic Zone (Zona Ekonomi Eksklusif/ZEE). The policy to manage Indonesian fisheries only emerged in the mid-1970s, through the Minister of Agriculture's Decree No. 561/1973 which requires all industrial vessels conducting shrimping to use all bycatch [16]. This Decree of the Minister of Agriculture was then followed by the issuance of a set of guidelines for the conservation and management of other fish resources.

As previously mentioned, the global goal of sustainability to be achieved in the field of marine and fisheries is to preserve and sustainably utilize marine and ocean resources for sustainable development. To achieve this then set in four global targets in 2020 include: (1) managing and protecting marine and coastal ecosystems in a sustainable manner to avoid significant adverse impacts, including by strengthening resilience, and carrying out restoration to realize healthy and productive oceans; (2) regulating harvest and stopping overfishing, illegal fishing and destructive fishing practices, and implementing science-based management plans, to restore fish stocks properly in the shortest possible time, at least to the level that can produce maximum sustainable yield according to biological characteristics; (3) conserving at least $10 \%$ of the coastal and marine areas, consistent with national and international law and based on the best available scientific information: and (4) prohibiting certain forms of fishery subsidies that contribute to overcapacity and overfishing, eliminating subsidies that are contributing to Illegal, Unreported, and Unregulated (IUU) fishing and withholds new types of subsidies, by recognizing that appropriate and effective special and different treatments for developing countries must be an integral part of negotiations on fishery subsidies at the WTO.

Given this complexity of achieving the objectives of fisheries management, what is being prepared is not only related to the legal framework but also nonlegal instruments such as issues of conservation, trade and marine safety. This is because sustainable fisheries management is also influenced by the social and economic conditions of a country, available scientific data, and administrative structures in place [17].

These predetermined indicators receive special attention and are integrated into the 2020-2024 RPJMN. Special efforts were made to ensure that regional development targets use the same indicators and are carried out in accordance with SDG's. The development targets set in the 2020-2024 RPJMN in the field of the Environment are more directed at institutional strengthening and law enforcement carried out by: (a) Strengthening regulations and institutions in the field of Natural Resources and the Environment in the Central and Regional Levels; (b) Strengthening licensing, supervision, and security system for the natural resource and environment management; and (c) Law Enforcement in the field of Natural Resources and the Environment.

To support the performance of the KKP in determining the supply of fish stocks in Indonesian waters, the Komnas Kajiskan has been formed. But unfortunately, the National Commission's recommendation does not yet have binding power. Finally, even though the KKP Regulation states that updating fish stock data is done every year, the data used is the recommendation of the last Komnas Kajiskan for 2015.

\section{IV.CONCLUSION}

Sustainable fisheries management is intended to provide a guarantee of food availability for current and future generations. Various laws and regulations in the field of fisheries have also been directed to support the program, including the 2020-2024 RPJMN. However, these various instruments have not yet been given a specific explanation related to the indicators of sustainable fisheries management achievements. Consequently, it will be difficult to assess whether the fisheries management is in accordance with SDG's.

\section{REFRENCES}

[1] The term "archipelagic nation" according to Yudi Latif contains a land bias. Interestingly, Soekarno once called the State of Indonesia a "country of the sea sprinkled with islands". That is more in line with the term archipelago, which means "sea power" (arch / archi = power; pelago $/$ pelagos = sea). Yudi Latif. 2019. Negara Paripurna : Historitas, Rasionalitas, dan Aktualitas Pancasila, $7^{\text {th }}$ print, PT. Gramedia 
Pustaka Utama, Jakarta, p. 2

[2] The term "archipelagic nation" according to Yudi Latif contains a land bias. Interestingly, Soekarno once called the State of Indonesia a "country of the sea sprinkled with islands". That is more in line with the term archipelago, which means "sea power" (arch / archi = power; pelago $/$ pelagos $=$ sea). Yudi Latif. 2019. Negara Paripurna : Historitas, Rasionalitas, dan Aktualitas Pancasila, $7^{\text {th }}$ print, PT. Gramedia Pustaka Utama, Jakarta, p. 2

[3] Diah Apriani Atika Sari, 2019, Integrasi Tata Kelola Kebijakan Pembangunan Kelautan Berkelanjutan, Rechtsvinding Journal, BPHN, h. 160

[4] Overfishing terjadi di Laut Aru, Laut Arafuru, Laut Timur termasuk di Laut Jawa. See Kementerian Kelautan dan Perikanan. 2017, Op.Cit., h. 13-14.

[5] Emmy Latifah, Perkembangan Pengaturan Pengelolaan Perikanan Berkelanjutan Berdasarkan Hukum Internasional, Jurnal Bina Mulia Hukum, Vol. 1 No. 2, 2017, h. 125.

[6] WWF. 2015. Menghidupkan Kembali Ekonomi Laut : Alasan Untuk Bertindak-2015 (Summary), p. 8

[7] Sekar Panuluh \& Meila Riskia Fitri. 2016. Perkembangan Pelaksanaan Sustainable Development Goals (SDG's) di Indonesia : September 2015-September 2016, Brifing Paper 02, www.infid.org, h. 5

[8] IGAK Rachmi Handayani, et.al. 2018. Environmental Protection Pattern Based on Regional Autonomy as The Effort to Realize Sustainable Development Goals, International Journal fot Studies on Children, Women, elderly and Disabled, Vol. 5, p. 134

[9] Peter Mahmud Marzuki. 2014. Penelitian Hukum. Jakarta: Prenadamedia Group, p. 237-240

[10] FAO, Law and Sustainable Development Since Rio - Legal Issues and Trends in Agriculture and Natural Resources Management, see also FAO Legislative Study 73 (Rome: FAO, 2002). Source:

https://www.fao.org/docrep/005/y3872e00.HT M, accessed on Juy 2020.

[11] Ibid. Part 3.2.1. the regime of ownership of fishery resources can take the form of: (1) state property; (2) private property; dan (3) common /collect property, p. 253

[12] Elinor Ostrom. Private and Common Property Rights, source: http://ecyclo.findlaw.com/2000book.pdf,

[13] Neil L, Andrew and Louisa Evans, 2011. Approaches And Frameworks for Mangement And Research in Small-Scale Fisheries, in
Robert S. Pomeroy dan Neil L. Andrew, SmallScale Fisheries Management Frameworks and Approaches for The Developing World, CAB International, UK, p. 20.

[14] See the Constitutional Court Decision Number 001-021-022/PUU-I/2003 on the Review of Law Number 20 of 2002 on Electricity and Constitutional Court Decision Number: 002 / PUU-I / 2003 on the Review of Law Number 22 of 2001 on Oil and Gas, these five aspects became one of the main parameters of the Constitutional Court in deciding the law related to article 33 paragraph (3) of the 1945 Constitution.

[15] IGAK Rachmi Handayani, et.al, Op.Cit., p. 137

[16] PSJK, Barunastra, et.al., Kerangka Hukum dan Tata Lembaga dalam Sektor Perikanan di Indonesia, Jakarta, 2019, p. 66

[17] Mary Ann Palma, Martin Tsamenyi, and William Edeson, Promoting Sustainable Fisheries : The International Legal and Policy Framework to Combat Illegal, Unreport and Unregulated Fishing, Vol. 6, Martinus Nijhoff Publisher, Leiden-Boston, 201 